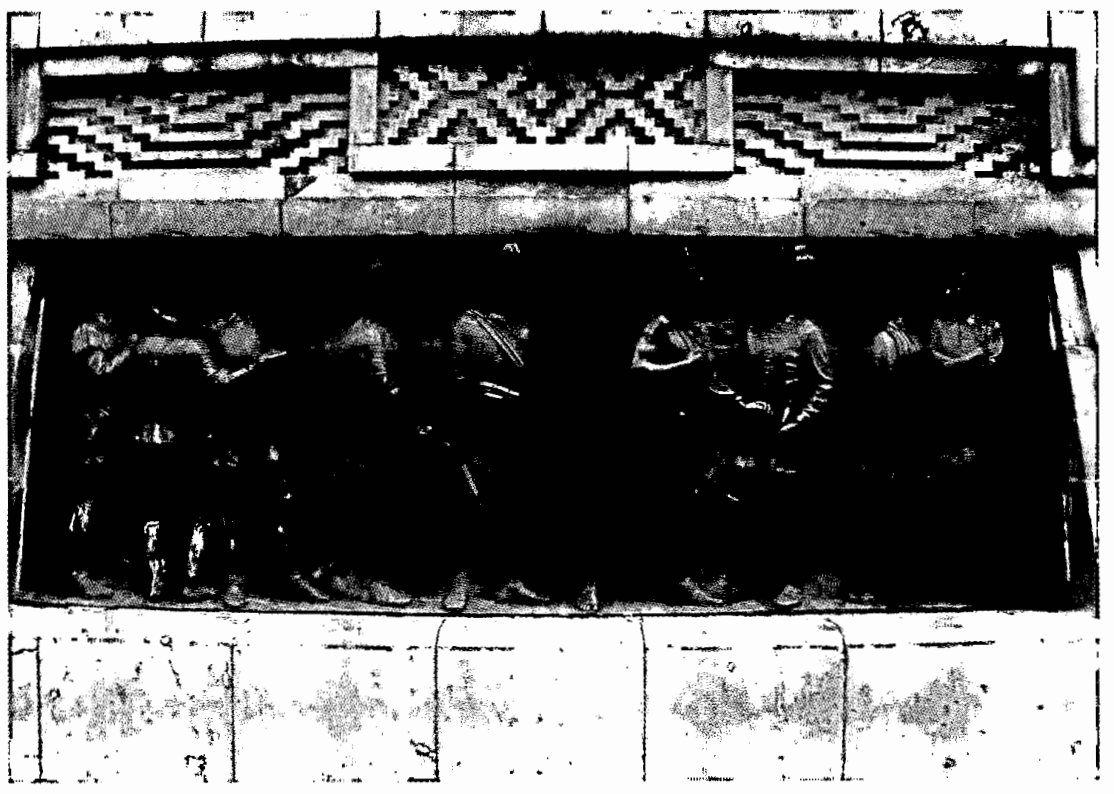




\section{Lourdes Roca / Fernando Aguayo}

Lourdes Roca. Investigadora del Instituto Mora y coordinadora del Laboratorio Audiovisual de Investigación Social, proyecto Instituto Mora/CONACYT. Doctora en Antropología e Historia y miembro del SNI. Se dedica a la investigación y la divulgación de la historia gráfica y la historia y antropología de la cultura visual de los siglos XIX y XX. Es autora y coautora de diversos artículos en revistas como Desacatos, Razón y Palabra, Antropológicas y Secuencia, así como de libros y documentales en video: $\mathrm{Km}$. C-62 Un nómada del riel, Plaza y Valdés/Instituto Mora/FONCA/CONACYT, México, 2000; La Cornela (1940). Punto de partida, INBA/FonCA/CNA, México, 2001, y Mi multi es mi multi, Instituto Mora, México, 1999, entre otros.

Fernando Aguayo. Candidato a doctor en Historia por la BUAP y maestro en Historia. Investigador del Laboratorio Audiovisual de Investigación Social (Instituto Mora/CONACYT). Su línea de investigación es la historia gráfica de los ferrocarriles y de la ciudad de México durante los siglos XIX y XX. Entre sus publicaciones destacan libros, exposiciones y documentales en video como Estampas ferrocarrileras. Fotografía y grabado (1860-1890), Instituto Mora, México 2003, y Revelando el rollo, Instituto Mora, México, 2002, vHS.

\section{Resumen}

El artículo aborda el tema de los usos sociales del espacio, tomando como ejemplo el Zócalo de la ciudad de México durante el periodo 1880 a 1885, cuando el Ayuntamiento incrementa las prohibiciones para la realización de cierto tipo de actividades en la plaza y establece cuotas según los usos de que se trate y las posibilidades de remuneración que representen. Con todo y este afán por reglamentar la utilización del espacio y la promoción de las fechas de conmemoración cívica, a través de diversas fuentes como las fotográficas se observa la persistencia por celebrar aquéllas de acuerdo con las tradiciones populares, con los consecuentes usos y apropiaciones del espacio en el Paseo del Zócalo.

Palabras clave:

Ciudad de México, Zócalo, espacio, fotografía, diversiones, siglo XIX.

\section{Abstract}

The article explores the issue of the social uses of space, based on the example of the Zocalo or Great Square of Mexico during the period 1880 to 1885 , when the Town Hall increased its prohibitions on undertaking certain types of activities in the square and established fees for various functions, in keeping with the possibilities of remuneration they offered. Despite the desire to control the use of space and the official promotion of civic ceremonies, several sources, particularly photographs, document the persistence of celebrating popular traditions, with the resulting uses and appropriations of public space in the promenade of the Zocalo.

\section{Key words:}

Mexico City, Zocalo, space, photography, entertainment, $19^{\text {th }}$ century.

Fecha de recepción: septiembre de 2003

Fecha de aceptación: diciembre de 2003 


\title{
Usos y apropiaciones de un espacio urbano. El Paseo del Zócalo, 1880-1885
}

\author{
Lourdes Roca \\ Fernando Aguayo*
}

$\mathbf{E}$ n el año de 1864 el Ayuntamiento de la ciudad de México informó que en las festividades de noviembre, recién concluidas, se instalaron ocho construcciones provisionales que habían albergado a otros tantos teatros en la plaza principal de la capital, además de que se había formado, como era costumbre, el salón del Zócalo. Terminada la tempora$\mathrm{da}$, los empresarios de los teatros establecidos en la plaza de armas solicitaron prorrogar sus funciones de títeres para los habitantes de esta ciudad hasta el 12 del entrante diciembre. El Ayuntamiento accedió a la petición y calificó las actividades de "sanas diversiones". Sin embargo, dos días después de esta respuesta, el ministro de gobernación informó a las autoridades que el emperador había

derogado esa disposición e indica que se le avise al alcalde municipal, para que a partir de esa fecha se quiten los teatros porque afean la vista y son una contraversión a las leyes de policía y ornato, de seguridad y de tranquilidad pública.

La prohibición era terminante. Arquitectos y urbanistas del imperio habían

* Agradecemos el apoyo de Citlali Salazar, quien participó como becaria del proyecto en la primera fase de esta investigación. diseñado cambios que transformarían por completo el espacio de la ciudad de México. De todas las propuestas sólo se inició la construcción del Paseo del Emperador, después conocido como Paseo de la Reforma, y se modificó la Plaza Mayor para crear un gran paseo que duraría hasta la primera década del siglo $\mathrm{xx}$ con esta función.

Una revisión de los vestigios documentales que tratan sobre las festividades que se desarrollaron en la plaza de la Constitución nos indica que esta posición ambivalente de las autoridades para permitir o prohibir las fiestas en este espacio era algo que se mantenía durante la segunda mitad del siglo XIX y que, tras sus opiniones encontradas, aparecieron decretos que las prohibían, considerados como medidas definitivas, sólo para que con el transcurso del tiempo esas formas de festejo y diversión aparecieran no sólo como solicitudes y respuestas a las peticiones, sino en fotografías que las captaron con gran detalle. ${ }^{1}$

${ }^{1}$ El día 6 de agosto de 2002 amanecimos en el Distrito Federal con la curiosa noticia de que se instaló un circo en la plancha del zócalo de la ciudad, lo que generó toda una serie de notas de prensa, radio y televisión durante más de una semana, así como una profusión de opiniones encontradas y comentarios al respecto. Los extremos de estas opiniones es- 
En el marco de una más amplia investigación acerca de los usos de la imagen en la investigación social, en el presente artículo exponemos una explicación a esta actitud contradictoria de las autoridades municipales hacia las fiestas, lo que, por otro lado, no es sino el pretexto para impulsar un objetivo intelectual mayor: contextualizar un cuerpo de imágenes e incorporarlas como fuentes de nuestra investigación sobre los usos y apropiaciones del espacio en el Zócalo capitalino durante la segunda mitad del siglo XIX y la primera del $\mathrm{xx}^{2}$

\section{¿POR QuÉ LA FIESTA?}

Podemos decir que, en términos generales, en las publicaciones de tipo histórico la imagen ha sido utilizada solamente

taban entre criticar el uso de un espacio privilegiado de la nación y los que aplaudieron esta diversión abierta a toda la población, especialmente a los niños. Entre estos puntos, toda la gama de opiniones se pueden encontrar también en el lustro que va de 1880 a 1885 , expresadas en principio por los integrantes de la Comisión de Diversiones Públicas que regía desde el Ayuntamiento los permisos para el uso festivo en el Zócalo capitalino, ya fuera para unos juegos de caballitos, o para un teatro de títeres. Sin embargo, aunque muchas fiestas venían de tiempo atrás y continuaron después de este periodo, lo que encontramos característico de este lustro es una posición firme del Ayuntamiento y medidas para controlar y orientar estas fiestas, lo cual se refleja en parte en los cambios que podemos observar en los criterios para conceder o no el permiso de instalar determinadas diversiones en algunas fechas específicas.

${ }^{2}$ Este artículo comparte ideas y conceptos expuestos en Ribera, Herencia, 2002, especialmente en el apartado "Organización de la vida ciudadana: servicios públicos y recreación”, pp. 174-256. como un elemento ilustrativo, como algo que se inserta sólo después de que los investigadores redactan su trabajo. Las imágenes, sobre todo las fotográficas, son producto de una mirada y un instante preciso que las produce, por esta razón, y atendiendo a una provocación expuesta hace años por John Mraz, ${ }^{3}$ decidimos invertir la forma tradicional de trabajar con las fotografías; es decir, que en este trabajo hicimos una selección de imágenes del lustro $1880-1885^{4}$ como punto de par-

${ }^{3}$ Véase Mraz, Ensayos, 1996.

${ }^{4}$ Uno de los problemas más significativos para trabajar con fotografías es el que se refiere a la poca importancia que se da a la catalogación rigurosa de ellas en la mayoría de los acervos que las contienen. En una de estas instituciones, una fotografía del Zócalo de la ciudad de México, realizada por la firma Gove \& North en 1883, tiene los siguientes datos: Autor no conocido, lugar no conocido, tomada cerca de 1920. Esta situación no es culpa sólo de los archivos fotográficos, sino que se inscribe más bien en una problemática relacionada con la valoración del acervo histórico nacional. Para tener una visión de esta situación, véanse los trabajos de Aguayo et al., Revelando, 2002, y Aguayo y Roca, Imágenes, en prensa. Este artículo no está inscrito en la línea de la historia de la fotografía, sin embargo, es preciso partir de una investigación acerca de las propias imágenes como un requisito previo a su utilización. De tal suerte que el señalamiento de que se hizo una selección de imágenes que corresponden a este periodo implica ya un trabajo de creación de nuestras fuentes que no carece de importancia, como bien saben los que trabajan con imágenes de una forma que va más allá de la figura pegada en un texto.

En este artículo, aunque se incorpora una como antecedente y otra de una fecha posterior, el objetivo fue trabajar únicamente con las fotografías que se generaron en el periodo: Lorenzo Becerril y Antíoco Cruces hacen un registro en 1880 , Jackson entre 1882 y 1883 , y los socios Gove \& North entre 1883 y 1885 , aunque especial atención recibe tanto en sus 
tida para ensayar las posibilidades que tienen las fotografías de tipo histórico para plantearse el diseño de nuevos problemas de investigación que nos ayuden a explicar de mejor manera la dinámica de las sociedades que estudiamos.

Las fotografías, antes que un espejo de la realidad, son artefactos construidos por diversos actores sociales que captan, en distintos formatos y con ciertas limitantes técnicas, un aspecto de la vida que se desarrolla frente a ellos. Del lustro señalado logramos localizar una veintena de imágenes fotográficas de la Plaza Mayor desde diversos ángulos y en diferentes momentos. En este universo encontramos que las fotografías más comunes son aquellas que se construyen queriendo mostrar la monumentalidad o belleza de la plaza y sus transformaciones desde el punto de vista arquitectónico o urbanístico. En estas impresionantes panorámicas los elementos vivos, sobre todo humanos y animales, no son protagónicos.

Son este tipo de imágenes las que en mayor medida se conservan en archivos públicos y colecciones privadas y, lo que es más interesante, las que más se reproducen actualmente en las publicaciones con temas históricos. Sin embargo, frente a ellas y a contracorriente del discurso que nos dice que el uso adecuado de la Plaza Mayor es contemplar su monumentalidad, localizamos otras que nos muestran parte de las festividades que tenían como escenario el Zócalo de la ciudad. ${ }^{5}$ Por eso

imágenes como en su texto la obra de Manuel Rivera Cambas, México pintoresco, artístico y monumental, cuyo primer volumen es editado en 1880 .

${ }^{5}$ En este trabajo se insertan doce imágenes, cinco que serían las clásicas vistas arquitectónicas (imágenes $3,4,5,6$ y 7 ) y otras siete que tienen como tema el hemos elegido el tema de las fiestas para construir nuestras fuentes gráficas, porque contienen elementos para el análisis social

registro del ambiente festivo en la ciudad (imágenes 1, 2, 8, 9, 10, 11 y 12). También hemos incluido una caricatura en la que se hace evidente no sólo la existencia de las diversiones de las que hablaremos, sino la postura crítica de la elite liberal ante ellas. Como se ha mencionado, considerar las imágenes como un artefacto creado por sujetos sociales con objetivos precisos nos obliga a mencionar escuetamente algunos de estos factores técnicos y su relación con el tipo de imágenes construidas. La primera imagen forográfica del Zócalo de la ciudad de México es un daguerrotipo realizado en el año de 1840 . El tiempo de exposición para la creación de este tipo de imágenes era de alrededor de 20 minutos, por lo que cualquier cosa encuadrada que se moviera en ese lapso aparecía en el resultado final como una mancha ininteligible. Atendiendo a esta razón, muchas de las imágenes del siglo XIX relacionadas con espacios urbanos fueron construidas explícitamente con la iclea de que no existieran elementos en movimiento, porque las técnicas fotográficas no lo podían captar. Con el transcurso del tiempo y gracias a la creación de nuevos instrumentos fotográficos, los tiempos de exposición bajaron de minutos a segundos. El progreso fue constante. Hacia 1850 aparecen las impresiones en albúmina, como son los originales a partir de los que se escribió este artículo. Si revisamos la fotografía del portal de Mercaderes de 1860, una albúmina publicada en el conocido libro (Tovar, Ciudad, 1992, t. I, p. 44), veremos varios barridos en forma de mancha en lo que corresponde a la plaza. En unos casos se trata de personas dirigiéndose a los portales, y en otros, probablemente de carretas rumbo a la calle 16 de Septiembre. Para 1880, momento de nuestro estudio, las posibilidades técnicas permitían captar a la multitud en la plaza. Las personas que se movieron en el momento de la toma, por ejemplo en el primer plano del lado izquierdo de la imagen 1, como sucede con una cámara común de hoy día, aparecen borrosas. Sin embargo, la plaza en su conjunto es movimiento y esto lo podemos apreciar en las imágenes de esta época. Nuestra hipótesis, entonces, es que si la ma- 
que no han sido considerados para trabajar la época.

En ellas podremos leer los ambientes festivos de cualquier domingo o hasta celebraciones como las del 15 de septiembre o el 5 de mayo, motivos que seguimos encontrando en tomas posteriores. Entre escenas de festivo bullicio podemos observar elementos como las pequeñas carpas y jacalones destinados a títeres, teatros, zarzuelas o carruseles y otros actos de diversión pública que, aun prohibidos por distintos ordenamientos, eran costumbre en este espacio. Un ángulo particularmente destinado a ello era el que forman el jardín del atrio con la plazuela del Seminario, donde seguido se observan este tipo de instalaciones durante días festivos, ya sean las tradicionales o las cívicas impuestas por el calendario liberal (véase imagen 1).

Conviene hacer un recuento de las distintas fiestas que tenían lugar de manera especial en la Plaza Mayor, para después hacer una selección de las que abordaremos en estas líneas. Rivera Cambas dice:

En el Zócalo tienen verificativo los paseos más concurridos, ya sea en el carnaval, Semana Santa, Todos Santos o en las fiestas cívicas del 16 de septiembre, 5 de mayo o de febrero; a los viajeros notables se les ofrecen allí conciertos nocturnos y bajo los gigantescos eucalyptus y los copados fresnos,

yoría de las fotografías de nuestro periodo de estudio corresponden a vistas arquitectónicas en las que las personas no aparecen o son algo secundario, no se debe a las limitantes técnicas que sí existían en la primera fase de la técnica fotográfica, con los daguerrotipos por ejemplo, sino a elecciones de los fotógrafos e instituciones o empresas que patrocinaban la creación de este tipo de imágenes. se forman casi diariamente reuniones dignas de una culta capital. ${ }^{6}$

De los cuatro tipos de reuniones que menciona Rivera Cambas nos centramos en los dos primeros que él mismo diferenciaba claramente: las reuniones populares, que tenían un componente religioso, y las cívicas. Un análisis que contemple la persistencia de las primeras y la transformación de las segundas será el eje de este texto.

\section{LOS INGRESOS DEL AYUNTAMIENTO Y LA FIESTA POPULAR}

Como se puede constatar en otro escrito del propio Rivera Cambas, a las elites del siglo XVIII y XIX les parecía reprobable que "cada individuo del pueblo de México se considerara con derecho incuestionable para disponer de las calles como de cosa propia". Por tanto, los buenos gobernantes tenían como una de sus principales tareas reprimir las costumbres que constituían la vida en la calle; en particular, que la gente comiera, bebiera o bailara en la calle, o lo que es lo mismo, que se divirtiera en espacios públicos.

${ }^{6}$ Rivera, México, 1880, pp. 125-126.

${ }^{7}$ Ibid., pp. XxIX-Xxx. En un libro ya clásico, Viqueira explica cómo llegaron las autoridades ilustradas a la condena de estas actitudes, y una interesante discusión historiográfica, que cuestiona la visión acerca de la diversión popular en esa época como "relajamiento" de las costumbres, propone más bien que "la difusión de las ideas ilustradas y el cambio de un sistema de valores a otro en la elite..." llevó a la condena de actividades tradicionales de la población de la ciudad de México. Viqueira, ¿Relajados?, 1987, pp. 279-280. 


\section{SECUENCIA}

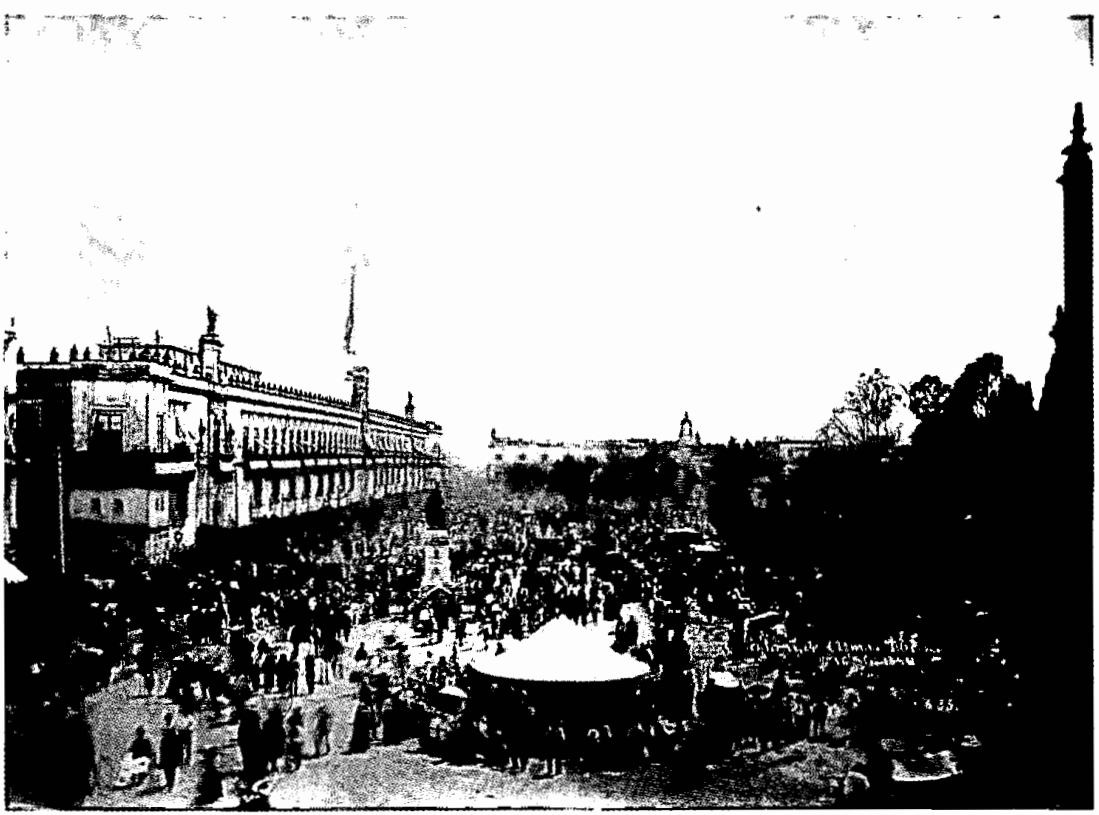

Imagen 1. Gove \& North, 635. Plaza de Armas, México, 16 de septiembre de 1883, ConacultaINAH-MEX, 456675. Reproducción autorizada por el INAH.

Con el triunfo de los liberales, además de poner énfasis en los lugares donde podían o no podían tener lugar este tipo de acciones, se prohibieron ciertas diversiones y juegos que se calificaron de perniciosos; las corridas de toros, peleas de gallos, los juegos de naipes y, en general, los de azar estuvieron desde entonces en la mira, y fueron perseguidos y hasta prohibidos en el Distrito Federal. Luego, aunado al dónde y al cómo, también se cuestionó el cuándo. Las pulquerías y la venta de pulque, producto con el que se enriquecieron más de uno de la elite de entonces, fueron señalados como formas que afectaban el trabajo y el orden; lo mismo sucedió con juegos como las canicas, que fueron elevados a categoría de enemigos que pierden el alma de los niños. En el camino de formar ciudadanos y trabajadores se intentó definir cómo, cuándo y dónde deberían divertirse los habitantes de la ciudad; sin embargo, estas celebraciones que la elite no compartía, les traían a la vez ganancias tanto a comerciantes como a un Ayuntamiento en constante penuria por sus ingresos. ${ }^{8}$

${ }^{8}$ López, Ciudad, 1985, p. 103, y Ribera, Herencia, 2002, pp. 239-240. 
De acuerdo con las fuentes documentales consultadas, los festejos que causaban más expectación eran los que iniciaban en noviembre:

Anímase el Zócalo principalmente en la temporada de Todos Santos, pues alrededor del espacioso y bello jardín se colocan teatros provisionales, salones con panoramas, títeres y mil puestos con dulces y calaveras de azúcar, curiosamente labradas. ${ }^{9}$

Es importante señalar que cada uno de estos "mil" puestos significaba ingresos para el Ayuntamiento. Haciendo un seguimiento del trabajo de la Comisión de Diversiones Públicas de esta corporación durante todo el lustro, ${ }^{10}$ se observa que en 1881 y gran parte de 1882 se autorizaron permisos para varias instalaciones, entre las que sobresalen los juegos de caballitos y teatros de títeres, por tratarse de un "asunto de niños" y, por lo tanto, no "inmoral", aunque precisando con claridad que son exclusivamente para instalarse en el día o días feriados indicados, para levantarse de inmediato al siguiente día. Una de estas construcciones provisionales fue captada por la cámara del fotógrafo H. W. Jackson (véase imagen 7). De hecho, desde tiempo atrás podemos encontrar grabados en los que se representa este tipo de diversiones, como por ejemplo, el detalle de una caricatura de Constantino Escalante publicada en La Orquesta del 23 de septiembre de 1867 (véase imagen 2); aunque, en este caso, la intención fue mostrar cómo "en este mun-

\footnotetext{
${ }^{9}$ Rivera, México, 1880, p. 125.

${ }^{10}$ Archivo Histórico del Distrito Federal (en adelante AHDF), Diversiones públicas, vols. 802 y 803.
}

do al revés", esa construcción y lo que representa de negativo para la elite liberal secuestran al buen teatro.

Es a fines de 1882 cuando empezamos a encontrar negativas a este tipo de solicitudes, externadas por las comisiones de Hacienda y de Policía. Sin embargo, pese a la ya notoria disminución en los permisos, en agosto de 1882 el Ayuntamiento acepta que en la temporada de Todos Santos se permitan puestos de diversiones en algunos lugares de la plaza, ${ }^{1}$ ya que constituirían un ingreso de noviembre a febrero de 360000 pesos para el Ayuntamiento. De esta manera se hace público el permiso, indicando la obligación de pagar un tercio de los ingresos al Ayuntamiento en todos los casos.

De acuerdo con el multicitado Rivera, uno de los mayores atractivos de la temporada era un salón que se formaba en el Zócalo:

se pasan las noches de temporada entre músicas, flores y perfumes. El Ayuntamiento se esmera en el adorno de ese local; allí se ven espejos, cuadros, vasos de colores, farolillos venecianos, juegos de luces y estrellas iluminadas por el gas, multitud de macetas con exquisitas plantas y bandas con los colores nacionales. ${ }^{12}$

Este espacio era el más atractivo también para rentar, por lo que el Ayuntamiento desplegaba un "aviso público" indicando el día en que se efectuaría "el remate del salón”. La corporación municipal señaló que la

\footnotetext{
${ }^{11} \mathrm{Ibid}$.

${ }^{12}$ Rivera, México, 1880, pp. 125-126.
} 


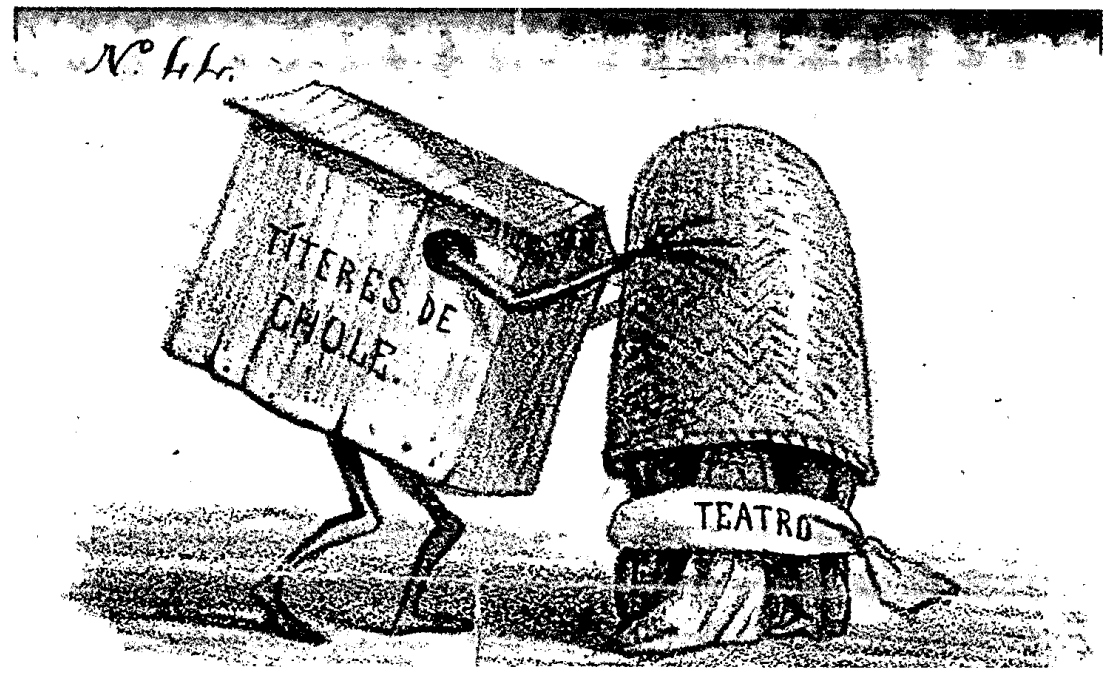

Imagen 2. Constantino Escalante, El mundo al revés (detalle), publicado en La Orquesta, 23 de septiembre de 1867 .

Comisión de Mercados está autorizada para conceder locales, con el fin de que los que soliciten puedan construir puestos de dulcería, juguetes y otras vendimias [...] igualmente [estaba] autorizada para proporcionar sitios a las personas que pretendan establecer salones y departamentos de recreo, y diversiones. ${ }^{13}$

También ofrecía servicios que contrataba con particulares para adornar e iluminar la plaza, además de proporcionar música para la tarde y noche. En esa temporada, la

13 AHDF, seccion Festividades de noviembre. Todos los Santos, exp. 1065. Se indicaban los espacios para cada actividad; por ejemplo, en 1872: dulces en el cuadro exterior del jardín y diversiones en la calle del Seminario. iluminación y la música permanecían hasta que se retirara la concurrencia. ${ }^{14}$

Sabemos que existían otro tipo de diversiones. Por ejemplo, para la temporada de muertos del año 1867 ciertos empresarios imprimieron un folleto que llamaba a asistir al "Salón del Zócalo" en donde se ofrecerían "óperas en miniatura". Las funciones eran diarias por tandas de una hora, y al final de cada una se presentaba un acto de magia. ${ }^{15} \mathrm{Y}$ aunque muchas se autorizaban, otras eran terminantemente prohibidas.

Siendo costumbre hacer una especie de feria en los ocho días de noviembre [escribió el se-

${ }^{14}$ Ibid.
${ }^{15}$ Ibid. 
ñor Nabor Muñoz], y deseando alquilar alguno de los locales que designe el excelentísimo Ayuntamiento para la colocación de jacalones, con el objeto de establecer en él un juego de lotería de cartones que, aunque está prohibido, puede, por la solemnidad de esta especie de feria y con la vigilancia debida de la autoridad como una gracia especial, conceder la licencia respectiva. ${ }^{16}$

La respuesta fue negativa, indicándole que los juegos de azar, entre ellos el de las loterías, estaban prohibidos.

En 1881, así como ocurrió también en 2002 cuando los Hermanos Vázquez instalaron su circo en la llamada plancha, los Hermanos Orrín montaron uno en la plaza de Seminario, ubicada en el extremo nororiental de la plaza. Eduardo Orrín no tuvo mayores complicaciones en obtener el permiso de la mencionada Comisión y plantar ahí la carpa con miras a estar presente en la temporada, es decir, noviembre y diciembre de aquel año. ${ }^{17}$ No se han localizado imágenes fotográficas de este circo mas que una realizada por Jackson en 1883 , en donde el objetivo era tomar una perspectiva de la calle de Moneda y en general del oriente de la ciudad desde catedral, y no el circo, cuya carpa despunta unos pasos detrás del monumento hipsográfico ${ }^{18}$ (véase imagen 3 ).

${ }^{16}$ AHDF, Diversiones públicas, vol. 819, exp. 28.

${ }^{17}$ AHDF, Diversiones públicas, vol. 802. Cabe mencionar que parecía representar un importante negocio para el municipio, no tanto por el centavo diario por metro cuadrado de renta del espacio, sino porque Eduardo Orrín ofreció donar al Ayuntamiento un sistema estadunidense para barrer y regar.

${ }^{18}$ En ese 1883 , Eduardo Orrín pide que una vez más se le conceda la plaza de Seminario para seguir con su circo durante una tercera temporada, de noviembre de 1883 a febrero de 1884 , en esta ocasión
A pesar de la abundante documentación escrita acerca de la ubicación del circo en este lugar, el hecho de no encontrar ninguna fotografía que lo encuadre, nos debe motivar a una reflexión. La imagen 3, como su título lo indica, fue realizada con el fin de mostrar una vista panorámica del oriente de la ciudad; es seguro que la parte del circo que se asoma tras el Sagrario no fue una situación que el fotógrafo quisiera destacar. La construcción ideológica de una imagen de ciudad, entendida ésta como un conglomerado de calles amplias y bellos edificios, tiene como base los discursos de la elite que la promueve y, en no menor medida, la de los artistas plásticos que, en el caso de los fotógrafos, hacen una cuidadosa selección de sus encuadres para mostrar esa imagen ideal.

Como hasta hoy sucede con buena parte de la fotografía de arquitectura, se seleccionan días, horarios y hasta se busca la cooperación de las autoridades para lograr el escenario ideal en el cual no aparezca gente, y así mostrar la "imagen perfecta". A pesar de ello, lo que vemos en las tomas no es absolutamente controlado por los operadores. Este es un claro ejemplo de las posibilidades de conocimiento que nos brinda la fotografía: sea porque el fotógrafo no logra controlar totalmente la escena o porque no toma en cuenta el escenario de lo que quiere captar, lo cierto es que aun en estas imágenes muy dirigidas existen elementos que escapan de la construcción original y por eso pueden ser motivo de un análisis distinto del ob-

se le autorizan $1313 \mathrm{~m}^{2}$. Y en el siguiente año se le concedió de nuevo, porque en compensación ofreció un pago al Ayuntamiento de 500 pesos para que se construyera un jardín en la plaza de Seminario. lbid. 


\section{SECUENCIA}

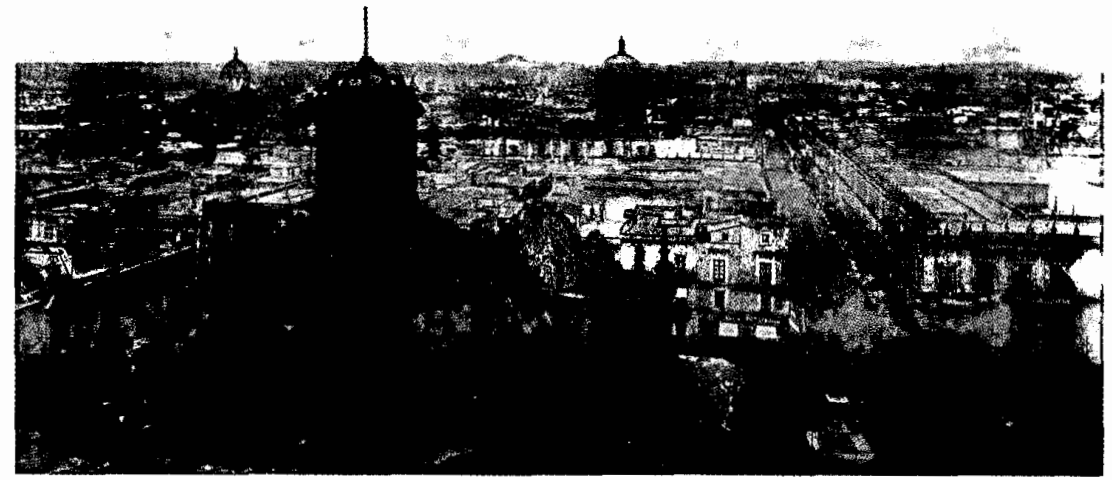

Imagen 3. W. H. Jackson, 5269, East from the Catbedral, 1883, publicado en Matabuena, Album, 2000 , p. 45.

jetivo que se pretendió en un origen con el registro en cuestión.

\section{LAS RESTRICCIONES}

Como ya se indicó, es a partir del año 1881 cuando se puede observar una tendencia a negar permisos para instalar diversiones en el Zócalo. Esta nueva postura es defendida en la proposición que hizo el regidor Pliego el 4 de mayo de ese año, en el sentido de ya no conceder en lo sucesivo licencias para establecer en la Plaza de la Constitución tiendas de campaña, jacalones, etc., destinados a cualquier género de diversiones públicas por las siguientes razones: 1) Embargan el uso público de la misma; 2) La afean y descomponen el piso de ella; 3) Presentan peligros contra las buenas costumbres y el mantenimiento del orden público, y 4) Dan ocasión a siniestros por la aglomeración de concurrencia y debilidad e improvisación con que se establecen. ${ }^{19}$

Más adelante, el 23 de septiembre de 1881, la Comisión de Festividades del Ayuntamiento decidió formar un "Proyecto para la festividad de los días de Todos los Santos y de Muertos". El proyecto tenía como objetivo evitar

los graves disgustos y las dificultades de todo género que han suscitado siempre al Ayuntamiento los jacalones que se han establecido en la plaza, los obstáculos que para la circulación han presentado cada vez mayores, la solicitud de puestos y construccio-

${ }^{19}$ AHDF, Diversiones públicas, vols. 802 y 803. 
nes ligeras que en estos días se acostumbra levantar. ${ }^{20}$

Podemos comprobar que la nueva posición prohibicionista no era algo definitivo al observar el contenido de algunas respuestas que daba la Comisión de $\mathrm{Di}$ versiones a las solicitudes para ocupar el espacio. En ellas se indicaban primero peligros e inconvenientes para inmediatamente después solicitar más detalles sobre la actividad de la que se trataba y el espacio a ocupar, como con fines de poderlo reconsiderar; no debería extrañarnos que otra razón de ese discurso fuera aumentar el precio de la renta a los posibles usuarios, aunque la tónica generalizada era responder con largas.

Los cambios de política para regular este tipo de permisos se hicieron patentes también en junio de este año al trasladarse a la policía la responsabilidad de la vigilancia y del orden de estos teatros, hasta entonces a cargo de los jueces de teatro. ${ }^{21}$ Podemos ver claramente manifestada la nueva postura del Ayuntamiento en el informe del 30 de enero de 1883 de la Comisión de Diversiones Públicas, publicado en Municipio Libre al día siguiente:

$\mathrm{La}$ Comisión que suscribe tiene a su cargo un ramo difícil, si se quiere que la capital se ponga a la altura que por su ilustración merece; y con profundo sentimiento manifestamos a ese honorable cuerpo que estamos

${ }^{20}$ En esta ocasión, el conocido discurso de la corporación tenía como justificación que "la formación reciente del jardín del atrio de catedral" había disminuido el espacio disponible, por lo que se propuso que las mencionadas festividades se verifiquen en la Alameda. AHDF, sección Festividades de noviembre. Todos los Santos, exp. 1065.

${ }^{21}$ Ibid. aún lejos de llegar a ese bello ideal. En efecto; nuestros teatros carecen, en su mayor parte, de las condiciones que para esos edificios se requieren. Nuestras diversiones se reducen, en algunas épocas del año, a inmundos jacalones y juegos de caballitos, que, con mengua del buen gusto y de la civilización se han permitido en nuestra Plaza de la Constitución. Por fortuna, en la actualidad, no carece la capital de espectáculos; y si continúa el movimiento que en ésta como en todas las líneas se ha despertado, pronto tendremos los que merece por la ilustración de sus habitantes. ${ }^{22}$

Con las negativas para la temporada de 1885 consideramos que concluye un ciclo: el de la plaza principal como espacio privilegiado para instalar tal variedad de diversiones; porque para entonces ya se había hecho público que en la plaza no se permitirían más este tipo de espectáculos y, aunque se mantenían instalaciones y diversiones en otro tipo de circunstancias, fue a partir de este año que las solicitudes comenzaron a proponer otros espacios autorizados para ello. ${ }^{23}$

${ }^{22}$ En el caso de Orrín, tanto por su éxito como por las prórrogas otorgadas por la Comisión y desde luego por la crecida cantidad de sus aportaciones, el circo permaneció cuatro años en la plaza de Seminario. Sin embargo, y pese a una larga tradición de instalar este tipo de carpas y teatrillos provisionales en diversos espacios del Zócalo (sobre todo frente a $\mathrm{Pa}$ lacio y en la plaza de Seminario), en 1885 podemos observar que el Ayuntamiento pone fin a este tipo de permisos, al no autorizar, a través de la Comisión de Diversiones Públicas, la instalación de ningún tipo de teatro, carpa o jacal temporal en ningún lugar de la plaza principal. AHDF, Diversiones públicas, vol. 803.

${ }^{23}$ Ya para la temporada de 1884 a 1885 , ningún permiso de juego de caballitos es autorizado frente al 


\section{LA FIESTA CIVICA}

Partimos de que la época que trabajamos se inserta en un proceso más amplio en donde la elite política construyó proyectos y realizó una serie de cambios para dar forma a la urbe de acuerdo con una idea de ciudad: un espacio eficiente, ordenado y limpio, en el que su belleza fuera reflejo de una ciudad amable para la salud de sus habitantes. Años antes había comenzado el cambio dramático de significación de la ciudad: de ser en su mayor parte un espacio sacralizado, donde los símbolos católicos se apoderaban de calles, puentes, plazas, etc., pasó a convertirse en una ciudad que intentaba sustituir a aquéllos por los símbolos de otra "religión" fomentada por una institución distinta, cuya principal finalidad era la formación de la nación. Así, a la ciudad se le sobrepondría poco a poco la máscara que la presentaría como lo que el régimen soñaba: una ciudad moderna, es decir, una que fuera calca de las capitales europeas, desde donde se rigiera a todo el país.

Los registros fotográficos dan cuenta también de este discurso que se busca construir sobre la ciudad y que los fotógrafos extranjeros reproducen a través de sus vistas. Vemos en estas imágenes, por

\footnotetext{
Palacio Nacional "por inconveniente". Y para la de 1885 a 1886, la instalación de un teatro provisional en la plaza del Seminario es concedida, pero afuera de la alameda. De la misma manera, por ejemplo a José Portilla, quien tenía tiempo con su teatro de época en dicha plaza, se le niega la solicitud de nueva prórroga en febrero de 1885 . Por lo que podemos concluir que es el Paseo de la Alameda la alternativa que las autoridades ofrecen a partir de ahí para el establecimiento de diversiones y sus respectivas instalaciones. AHDF, Diversiones públicas, vols. 802 y 803 .
}

ejemplo, que la decisión de construir un monumento hipsográfico en la plaza de Seminario, que de alguna manera celebrara la victoria de la ciudad sobre la naturaleza, se va materializando, primero con el pedestal que podemos ver instalado cuando inicia el lustro (véase imagen 4) y más tarde, después de cierta demora, con todo y el monumento, dando pie a nuevas vistas del Palacio con este nuevo mobiliario urbano.

Aunque con una ubicación distinta, el monumento hipsográfico aún permanece en el Zócalo. Otras instalaciones corrieron con peor suerte al ser primero reubicadas, luego totalmente reconstruidas, para finalmente desaparecer; podemos ver imágenes que se registraron de otras obras que no sobrevivieron ni el lustro que estamos trabajando, como el mercado de flores y plantas que podemos ver en un registro de 1880 de Lorenzo Becerril, ubicado en el lado poniente de la plaza principal y de efímera existencia (véase imagen 5). Poco después, en otra imagen producida por la firma Gove \& North, podemos observar el nuevo y flamante jardín del atrio, que presenta un espacio de diseño curvilíneo repleto de veredas para transitar por él entre esculturas y jóvenes árboles (véase imagen 6).

Sin embargo, en 1883 la realidad todavía no era la que soñaban los más ilustres liberales, pues según ellos México era

una pobre ciudad calumniada en sus atmetivos y en sus defectos. No tiene más que un centro en que palpite un poco de sangre arterial -el Zócalo. No tiene más que una gran vena un poco hinchada, la avenida de Plateros [...] No tiene más que dos imanes que atraigan a la concurrencia - la religión y la música. Donde quiera que se exhibe un 


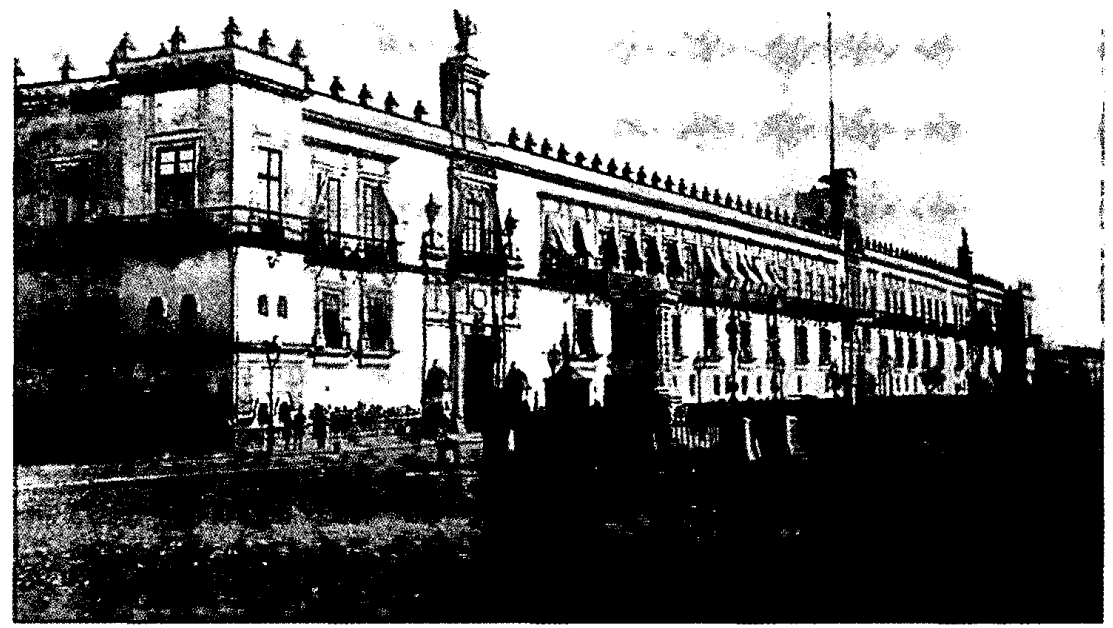

Imagen 4. Autor no conocido, sin título, ca. 1880, publicada en Matabuena, Album, 2000, p. 19.

clérigo vestido de brocado, o que se levanta un músico con un fagot, allí acude luego una muchedumbre de los dos sexos. ${ }^{24}$

Debemos anotar que el Ayuntamiento, y en general las autoridades, proporcionaban el marco para la diversión de esta "muchedumbre", otorgando iluminación para Todos Santos o la noche del martes del carnaval en el "zócalo de la plaza de Armas”. Esta situación se explica, según el Ayuntamiento, porque al dar los permisos se "ayudaba a empresarios sin elementos", "los niños tenían diversiones

${ }^{24}$ Ignacio Manuel Altamirano, "La vida de México", 1880, publicado por primera vez en Paisajes $y$ leyendas, 1884, en Altamirano, Obras, 1986, p. 81. sanas", "puestos donde comprar juguetes", etc.; pero, como hemos visto, también porque al hacer tratos con los que llamaban "especuladores sin escrúpulos", 25 que hacían sus negocios en el Zócalo, el Ayuntamiento recibía entradas considerables.

Algunos autores han explicado la transformación en las celebraciones como una entrada a la llamada modernidad. ${ }^{26}$ Sin embargo, como se puede constatar en algunas crónicas que se conservan hasta inicios del siglo $\mathrm{xx}$, a pesar de que ya no existían las instalaciones en las que se desarrollaban estas diversiones, la gente

${ }^{25}$ AHDF, Diversiones públicas, vol. 802.

${ }^{26}$ Moya, "Festejos", 2001. 


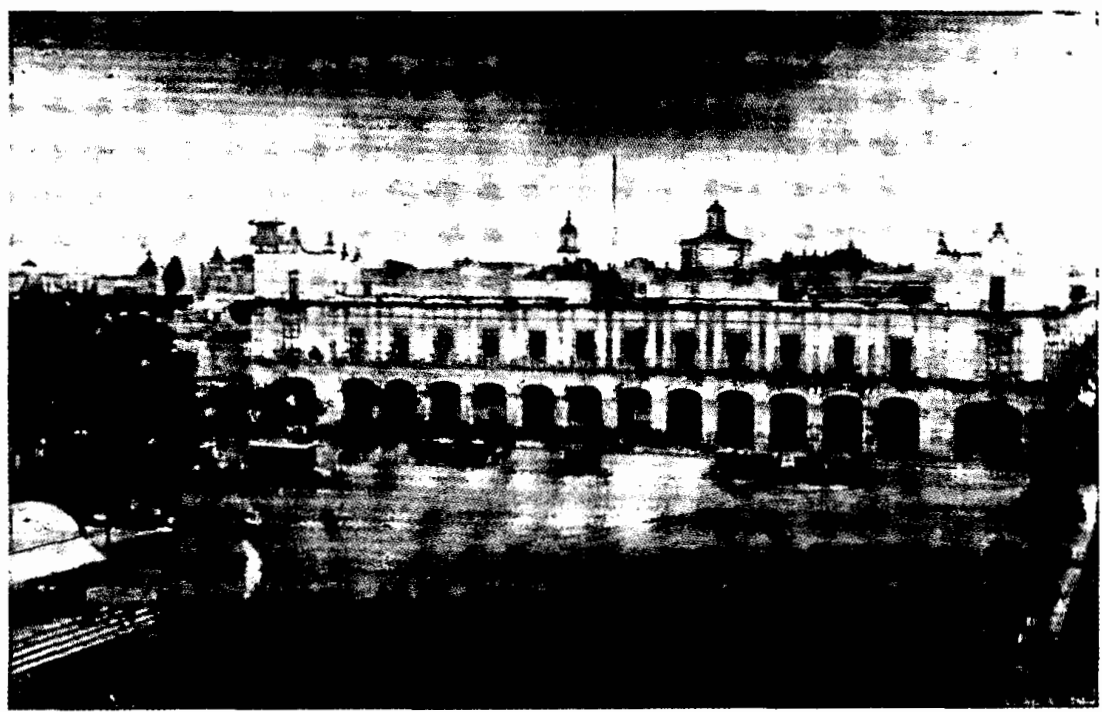

Imagen 5. Lorenzo Becerril, sin título, ca. 1880, CONACULTA-INAH-MEX, 26-79. Reproducción autorizada por el INAH.

asistía en las fechas tradicionales a celebrar de manera tradicional; aun más, impregnó las fiestas "cívicas" con sus maneras de celebrar (véase imagen 1), y eso podemos verlo de manera muy particular en los registros fotográficos.

Como hemos visto con Rivera Cambas, las fiestas cívicas más importantes de la época eran varias: el 5 de febrero que conmemoraba la promulgación de la Constitución de 1857 , la de la batalla de Puebla el 5 de mayo, y las relacionadas con la independencia, que estuvieron divididas primero entre el 15 y el 16 de septiembre, frente a su consumación, que se celebraba el 27 del mismo mes. Las cantidades que el gobierno federal suministraba para hacer frente a estos gastos iban en continuo aumento, y lo mismo sucedía con las festividades para conmemorar la independencia, que por estas fechas andaban en 5000 pesos. Al inicio de la vida independiente de México, lamentando tan fiesteras costumbres, Alamán afirmaba que muchos extranjeros querían "demostrar la incapacidad de los mexicanos para gobernarse, presentando a México como un pueblo que vivía en el caos y el ocio sin más preocupación que la de tirar cohetes día y noche". ${ }^{27}$ Esta aversión hacia la fascinación que les producían los fuegos artificiales a la mayoría de la población era compartida por la mayoría de la elite a fines del siglo XIX; sin

\footnotetext{
${ }^{27}$ Valadés, Orígenes, 1982 , p. 96.
} 


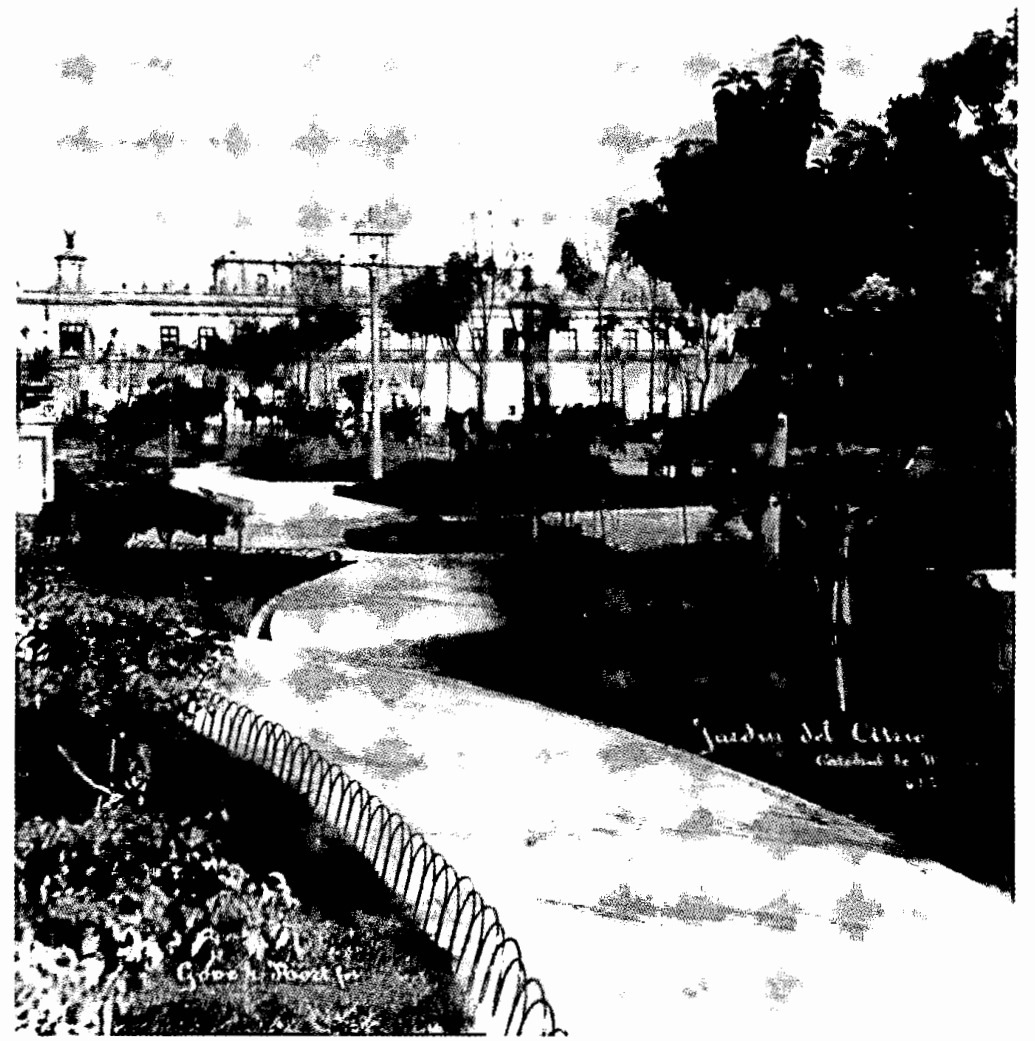

Imagen 6. Gove \& North, 605. Jardín del atrio, catedral de México, CONACULTA-INAH-MIX, 456573. Reproducción autorizada por el INAH.

embargo, en la celebración del 16 de septiembre de 1881, la corporación municipal gastó 1200 pesos en fuegos artificiales, eso sí diseñados "patrióticamente". 28

Podríamos hacer una crónica gráfica paralela a la planeación de las autorida-

\footnotetext{
${ }^{28}$ AHDF, Diversiones públicas, vols. 820 y 1071.
}

des: ${ }^{29}$ primero, con el tipo de tomas por medio de las que se quería destacar algún edificio o monumento, en este caso el Palacio Nacional (véase imagen 7), en un momento en el que no vemos circular a

${ }^{29}$ En 1884, para celebrar el 27 aniversario de la promulgación de la Constitución, el Ayuntamiento 


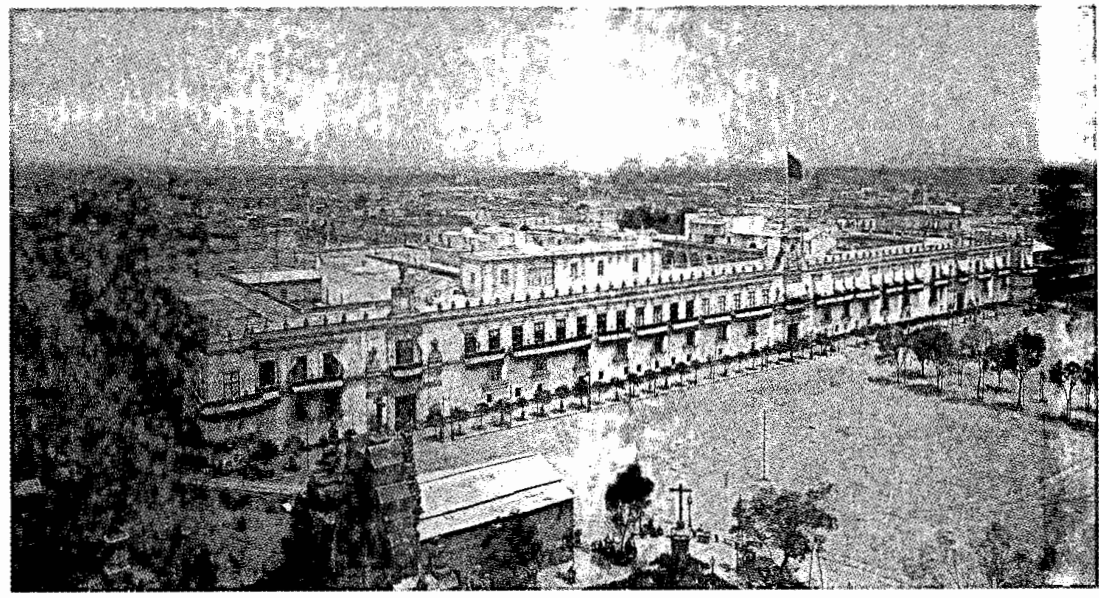

Imagen 7. W. H. Jackson, 5265, Mexico. Panorama from the Cathedral, the Palace, 4 de mayo de 1883, publicada en Matabuena, Álbum, 2000, p. 44.

nadie; luego, con el cuadro formado para hacer honores a la bandera, con todo y los cañonazos de rigor para celebrar, en este caso, a los héroes del 5 de mayo (véase imagen 8); y finalmente, en completo contraste, el bullicio en los momentos del

de la ciudad imprimió volantes media carta y pegó carteles grandes en los que se difundía el programa de las celebraciones que iniciaban haciendo gran bulla por todos lados: “Al rayar el alba se izará el pabellón nacional en los edificios públicos; habrá un repique general en los templos de la capital, y una salva de 21 cañonazos y las bandas de los cuerpos de la guarnición recorrerán las principales calles tocando dianas." Siguen los actos cívicos inaugurando talleres en las escuelas, en las que se pronuncian discursos y se lee poesía, a la vez que se tocan "músicas militares". Después se inauguran más obras públicas, y ya en la tarde, las músicas militares se sitúan en los paseos públicos y se conceden "funciones de circo gratis en las plazas de Santa Ana, Loreto, Tecpan de San Juan festejo popular (véase imagen 9). ${ }^{30}$ Además, si quisiéramos podríamos acercarnos y ver con detalle todo aquello que escapa a primera vista: en la imagen 1 vemos en primer plano los juegos de caballitos, y junto a las rejas de la catedral, los "in-

y de Juan José Baz. En la noche [concluye este programal se iluminará el jardín del Zócalo, verificándose allí una serenata que terminará a las doce." AHDF, Festividades diversas, vol, 1058.

${ }^{30}$ Podemos ilustrar el mecanismo por el cual se transforma el registro de un instante en una serie de "vistas" con las tres imágenes comentadas aquí. Todas fueron realizadas con motivo del 5 de mayo en la secuencia comentada, sin embargo, la primera se desprende de la fecha de celebración para convertirse en una imagen del Palacio Nacional, mientras que a las otras dos se les invierte la secuencia en que se tomaron; esto si hacemos caso al número que le asignó la empresa editora de imágenes. 


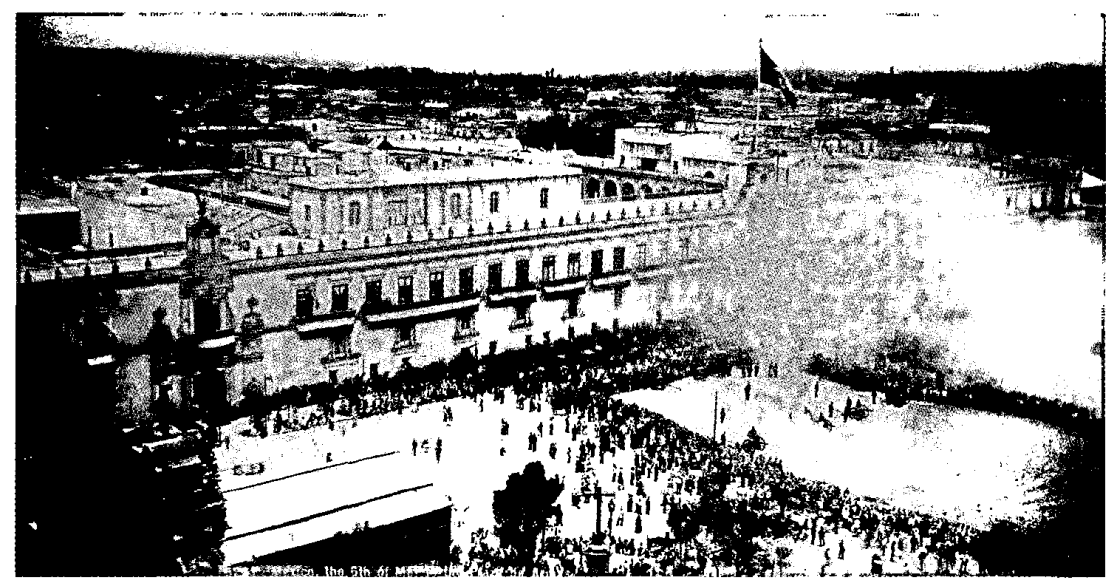

Imagen 8. W. H. Jackson, 5267. Mexico, the 5th of May, in the Plaza de Armas, 5 de mayo de 1883, publicada en Matabuena, Album, 2000, p. 46.

mundos jacalones" que albergan diversiones, comida y, de seguro, bebida.

\section{LA CIUDAD DE MÉXICO 1880-1885}

Más allá del Zócalo y de Plateros [...] la anemia, la melancolía, los murmullos prosaicos, el hormigueo de los pobres, la pestilencia de las calles desaseadas, el aspecto sucio y triste del México del siglo Xvı, las atarjeas asolvadas, los charcos, las montañas de basura, los gritos chillones de las vendedoras, los guiñapos, los coches de sitio con sus mulas éticas, y sobre todo esto, pasando a veces un carro de los tranvías como una sonrisa de la civilización, iluminando este gesto de la miseria y de la suciedad. ${ }^{31}$

${ }^{31}$ Altamirano, "La vida de México", 1880, publicado por primera vez en Paisajes y leyendas, 1884 en Altamirano, Obras, 1986, t. v, p. 82.
Durante el lustro de 1880 a 1885 se percibe entre los integrantes de los ayuntamientos la preocupación por promover obras que reflejen la eficiencia en el funcionamiento de la ciudad, sobre todo en la eterna lucha de este proyecto urbano contra la naturaleza: la imposible convivencia con el agua, aquella que existía naturalmente en la ciudad y que aumentaba en tiempos de lluvia; esta situación era complicada por la ubicación de la ciudad en una cuenca. ${ }^{32}$

Para 1880 la ciudad tenía una serie de canales abiertos que disminuían la cantidad de agua que entraba a la ciudad y a

32 Para su remedio, el Ayuntamiento apostaba a una serie de medidas: el contrato de desagüe y saneamiento de la ciudad y Valle de México, que consistía en el establecimiento de atarjeas con inclinación para que fueran desazolvadas con corrientes de agua. Ayuntamiento, Discurso, 1884, p. 45. 


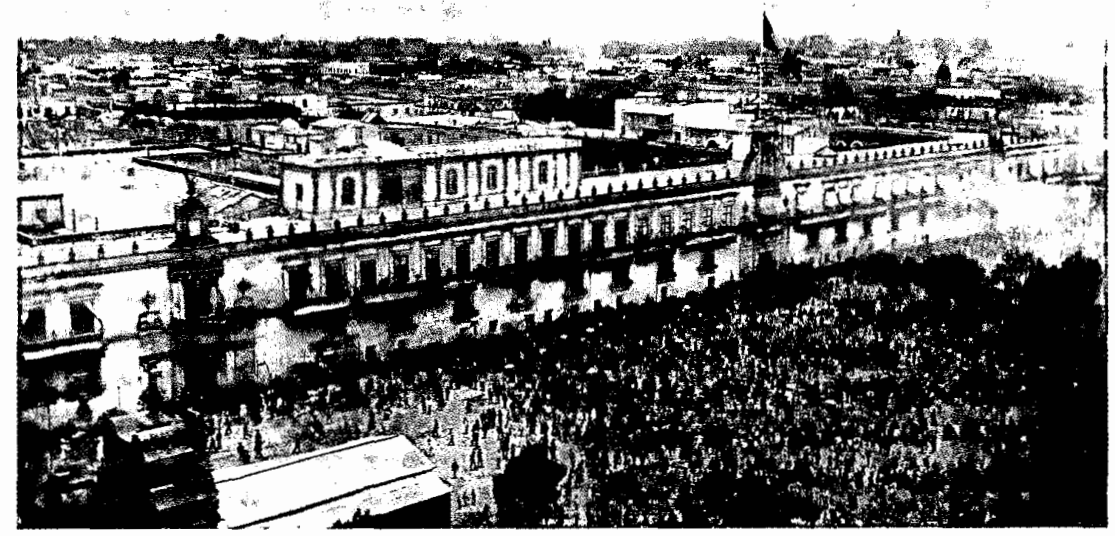

Imagen 9. W. H. Jackson, 5266. Mexico, the 5th of May, in the Plaza de Armas, 5 de mayo de 1883 , publicada en Matabuena, Album, 2000, p. 46.

la vez facilitaban la salida de las interiores; muchas de sus calles bajas se nivelaron para que ya no se anegaran más. ${ }^{33}$ Con todo, el sistema de atarjeas era incompleto $e$ ineficiente, lo que implicaba en algunas zonas el servicio de pipas que recolectaban los excrementos. En la parte de la ciudad donde el problema era más cotidiano había que limpiarlas continuamente, sin embargo, esta tarea la cumplían apenas parcialmente, por convenio pactado, el Ayuntamiento y la Compañía de Ferrocarriles del Distrito Federal.

Además, en 1885 se logró construir el rastro para cerdos, ayudando de esta manera a mantener más limpia la ciudad, ya que era en la calle donde se sacrificaban los animales, sus restos eran arrojados a las atarjeas, donde permanecían estanca-

${ }^{33}$ Ayuntamiento, Discurso, 1881, p. 20. dos por varios días. ${ }^{34}$ Los hábitos de los habitantes de la ciudad no respondían a la conducta que exigía el Ayuntamiento; se lee por ejemplo en la Memoria de 1882 de esta dependencia:

El gobierno del Distrito, fecundo en iniciativas para mejoras en la ciudad, se sirvió recomendar la construcción de unos inodores y lavaderos públicos en cuatro puntos de la ciudad [...] dificultades insuperables para la Dirección de Obras Públicas, no le permitieron llevarla a cabo [...] la importancia de esta mejora me obliga a llamar sobre ella la atención del nuevo Ayuntamiento, encareciéndole su ejecución, por abrigar la creencia de que para la buena higiene del centro de la ciudad se debe asear y atender hasta donde sea posible la circunferencia de la misma,

\footnotetext{
${ }^{34}$ Ayuntamiento, Discurso, 1886, p. 5.
} 
evitando los focos de inmundicia, llamados muladares, que no pueden menos de ser nocivos a la salubridad pública. ${ }^{35}$

Finalmente, el factor comercial es otro de los que presentan importantes cambios en este lustro: en 1880 se construyó el mercado de la Merced; en 1881 se remató el mercado de Jesús por no producir rentas, se reconstruyó el mercado de Santa Catarina y se construye el de San Juan Carbonero; en 1882 se abrió el mercado 2 de Abril; y, por último, en 1884 se inauguró el mercado de Santa Ana. Pero además, en 1882 el Ayuntamiento solicitó un empréstito para construir un rastro general y convertir en bazar de objetos de lujo el mercado del Volador. Evidentemente se buscaba descentralizar el comercio de la ciudad y en particular sacarlo del Zócalo; sin embargo, la persistencia de numerosos vendedores ambulantes en la calle hizo necesario tomar otras medidas de control del espacio público que se usaba para estos fines.

En 1884, el mismo año en que se publicaron las líneas de Ignacio Manuel Altamirano con que abrimos este apartado, regresó a nuestro país el francés Desiré de Charnay, quien de las impresiones de su nuevo viaje señalaba que la fisonomía de la ciudad de México había cambiado mucho. La mal empedrada Plaza Mayor - escribe Charnay- está convertida en un hermoso jardín: árboles, plantas, música todas las noches y los domingos de once a doce de la mañana. "En muchos puntos se han construido elegantes casas de estilo moderno; nuevos barrios ocupan solares de conventos derribados", ${ }^{36}$ esto escribe

\footnotetext{
${ }^{35}$ Ayuntamiento, Reseña, 1882, p. 18.

${ }^{36}$ Charnay, "Descubrimientos", 1884, p. 270.
}

además de sus observaciones sobre otras transformaciones físicas de la ciudad.

De esta manera, escritores, viajeros, ideólogos del liberalismo convertidos en funcionarios, hombres de ciencia y otros personajes ilustres de esta época, como Altamirano, Charnay, Rivera Cambas, Antonio García Cubas y otros más, expresaron su opinión sobre los cambios que vivía la ciudad: aumentaba su población y se construían nuevos sitios atractivos para la vivienda, "la ciudad se ensancha, se ha desbordado sobre los barrios de los indios, desconoce los linderos de la antigua traza y avanza hacia el poniente en busca del agua y de más benigno clima", 37 expresaba Rivera Cambas.

Aunque era un proyecto diseñado desde el imperio de Iturbide y reeditado una y otra vez, en esta época se empezaba a concretar por fin la propuesta de crear un eje privilegiado que fuera desde la Plaza Mayor hacia el poniente de la ciudad. Con ese objetivo, entre los paseos de la Reforma, de la Alameda y del Zócalo lucía brillante la arteria consentida de todos, la calle de Plateros. Para dar curso a este proyecto, el Ayuntamiento tenía la preocupación prioritaria de hacerse de recursos, ya que los que tenía - que eran escasos- los canalizaba a otros rubros más urgentes. Aun así, en el año de 1881 se comenzó a alinear la calle 5 de Mayo, ${ }^{38}$ para después pavimentarla con adoquines y banquetas de losas de Guanajuato, al igual que en las calles de Plateros y Palma (véase imagen 10 ).

Sin embargo, los problemas con las otras zonas de la ciudad, y sobre todo sus habitantes, persistían como otra preocupa-

\footnotetext{
${ }^{37}$ Rivera, México, 1880, p. xxxuII.

${ }^{38}$ Ayuntamiento, Discurso, 1882, pp. 6-9.
} 


\section{SECUENCIA}

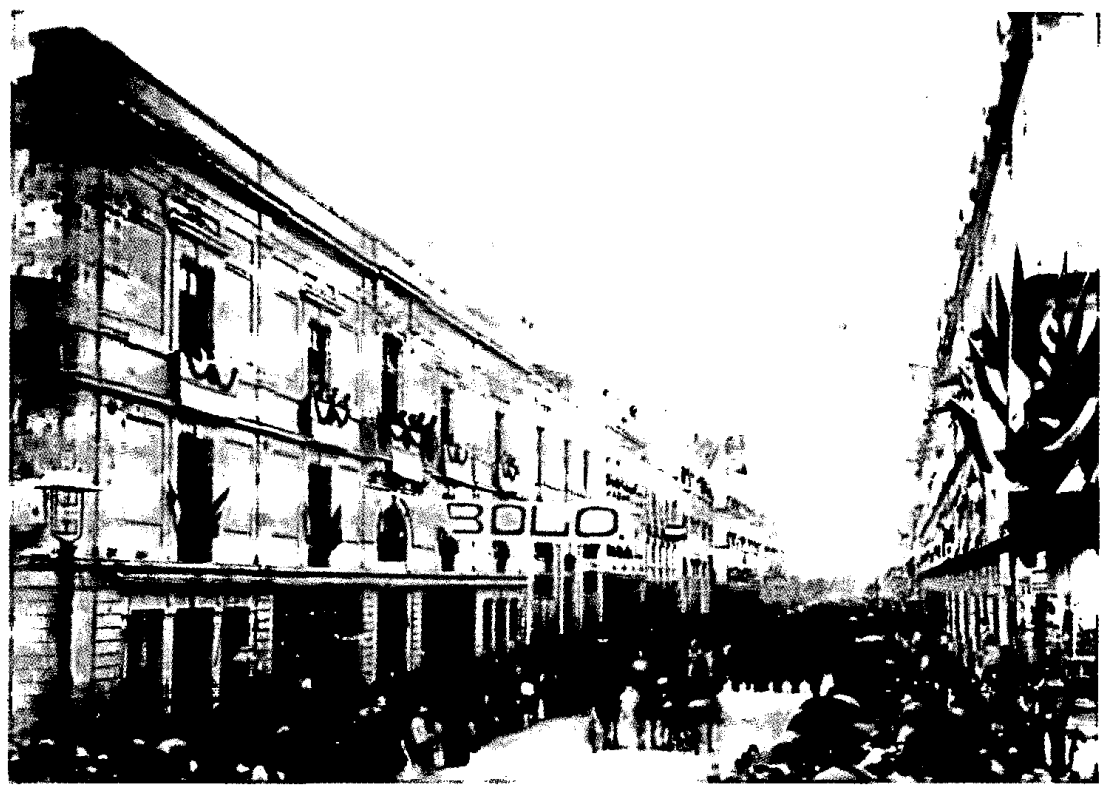

Imagen 10. Gove \& North, Avenida del Cinco de Mayo, 16 de septiembre de 1883, colección particular.

ción común a todos estos personajes: "el indio, siempre el mismo, parece inmutable como el destino; en punto a alimento, traje y costumbres, lo veo hoy tal como lo vé́a hace 23 años, $y$ tal como vivió hace diez siglos y más", 39 apunta Charnay coincidiendo con Altamirano en que esa parte de la población era una reminiscencia del pasado. García Cubas les hacía coro con la siguiente conclusión a la que llegó en sus estudios sobre la población de la ciudad:

Si consideramos al indio desde que nace, y aun antes de nacer, no vemos otra cosa que

${ }^{39}$ Charnay, "Descubrimientos", 1884, p. 270. una serie de miseria y de abyección [...] Los datos estadísticos, por imperfectos que hayan sido, han dado fuerza y valor a la opinión, que para mí es un hecho de que la raza indígena se debilita y decrece a la vez que se vigoriza y progresa la raza blanca. Este hecho está en perfecto acuerdo con las leyes de la naturaleza. ${ }^{40}$

A tono con esta creciente insistencia por parte de los miembros del Ayuntamiento en destinar recursos para sanear los "muladares" que estaban hacia las orillas de la ciudad, Rivera Cambas alerta sobre la amenaza de que este otro tipo de

${ }^{40}$ García, Apunte, 1870, p. 306. 
gente non grata se instale en la ciudad, y García Cubas recomienda que se eliminen aquellas zonas sustituyéndolas por árboles.

En cuanto a la distribución de agua potable, sobre la que existían muchas quejas, en 1881 se desarrolló un plan que consistió en entubar las aguas potables de la ciudad, procediéndose a la compra de tubos en Glasgow, Inglaterra. Con el fin de hacerse de recursos para ello, el Ayuntamiento obtuvo las ganancias de la venta del edificio de la ex Acordada, y al año siguiente, el Monte de Piedad le concedió un préstamo. Sin embargo, las cosas iban bien sólo en apariencia porque, como apunta Rodríguez Kuri en su interesante trabajo sobre los servicios públicos y los gobiernos locales, el fracaso de los distintos proyectos para dotar de agua a la población de la ciudad de México en este lustro tiene su raíz en el hecho de haber dado curso a un contrato que un particular propuso a la corporación municipal para arrendarle por 50 años el ramo completo de agua potable de la ciudad, incluyendo manantiales, acueductos, represas, tuberías, tomas y demás.

A pesar de las voces en contra, el contrato se llevó a cabo por parte del Ayuntamiento de 1884 , para que al siguiente año la nueva corporación diera marcha atrás al acuerdo, acusando a la anterior de

pasar sobre las prescripciones reglamentarias más claras y terminantes, con el fin de llevar adelante un asunto que contradice la ley, que condena la razón, que pugna con las facultades del Ayuntamiento, y que es manifiestamente contrario a la conveniencia de la ciudad [...] en el que el interés de lucro se opondría al buen servicio público. ${ }^{41}$

4l Rodríguez, "Gobierno", 1999, p. 171.
Sin embargo, de acuerdo con Rodríguez Kuri, esta postura del Ayuntamiento de 1885 no se da por motivos puramente doctrinales o de interés de cuerpo, sino atendiendo a los reclamos que se dan en distintos sectores de la población, en particular de la prensa que tuvo un papel central.

Lo mismo sucedía con las celebraciones. Todas estas transformaciones materiales de la ciudad, que son a la vez modificaciones de las formas de vida de sus habitantes, deberían de exaltarse junto con los días consagrados a la nación. Por ejemplo, para la celebración del día de la independencia el 16 de septiembre de 1883, se programó elogiar también el avance de las obras de conducción de agua potable a la ciudad y la apertura de la calle de 5 de mayo (véase imagen 10).

Esos días de "celebración cívica y del progreso material" iniciaban con gran estruendo, repiques de campana, dianas tocadas por bandas militares y hasta cañonazos para llamar la atención de la población. Luego venían los desfiles de artesanos, empleados del gobierno y estudiantes; más tarde las inauguraciones de obras públicas junto con discursos y poemas dedicados tanto a la nación como al progreso. Esos días de emociones tan fuertes culminaban con las citas para escuchar música selecta en los paseos públicos y con la retirada de los agradecidos ciudadanos que se irían a descansar y alistarse para la jornada laboral del siguiente día; claro, no sin antes comentar las enseñanzas morales y cívicas que transmitieron sobre todo los discursos y las declamaciones del conjunto de la jornada. Esto hacían los liberales convencidos, sin embargo, lamentablemente para ellos, los liberales eran una minoría de los habi- 
tantes de la ciudad de México; la mayoría, la muchedumbre a la que hacía referencia Altamirano, era atraída además por la música y el baile, la comida y la bebida, y tenían maneras propias de realizar sus celebraciones.

Las fiestas "cívicas" y de celebración del "progreso", según podemos ver en la imagen 1 , se realizaron en el Zócalo incluyendo elementos de las fiestas tradicionales y juegos, además de bebida y comportamientos licenciosos, de acuerdo también con crónicas que continúan hasta inicios del siglo XX. ¿Cómo se dio este proceso?, ¿eran los intelectuales liberales los que encabezaban estas celebraciones después de bajar del podio o soltar la pluma? Seguramente no. Se trata más bien de que la elite aceptaba la inclusión de estos componentes como una necesidad de garantizar que las fiestas cívicas y de culto al poder fueran concurridas y atractivas para la mayoría del pueblo; es decir, tenían que aceptar algo que la población les imponía por fuerza, algo con lo que doctrinariamente no estaban de acuerdo.

\section{LA CIUDAD, EL ZÓCALO Y LA FIESTA}

El ambiente festivo en el Zócalo se proyectaba desde la plaza principal hacia otros lugares. En cualquier domingo común y corriente se podía observar el trajín del transporte, incluidos coches y tranvías, partiendo del lado sur de la plaza hacia diversos destinos de la ciudad y alrededores a los que la población solía trasladarse de paseo, descanso y diversión (véase imagen 11). ${ }^{42}$ De los usos sociales de este es-

\footnotetext{
${ }^{42}$ Véase Aguayo, "Ferrocarriles", 1998, pp. 187199.
}

pacio hemos destacado de manera particular los festivos que, aunque de manera más escasa, también aparecen explícitamente en fotografías de la época, algo eclipsados entre el mayoritario universo de vistas arquitectónicas y urbanas. Esto tiene una razón de ser: las fiestas y diversiones populares eran para Altamirano, como para muchos liberales, un infierno de condena alejado del cielo cívico.
En cuanto a [...] las reuniones sociales [...] el espectáculo del Zócalo es uno mismo des- de que Trigueros plantó los arbolillos que hoy le dan sombra. ¡Siempre la gente dando vueltas alrededor del quiosco o en el cua- drilátero, como los condenados de Dante en los círculos del infierno! Una que otra vez se alza una tienda y se pone un café. Esto dura un mes, el de noviembre; siempre que un regidor joven en el Ayuntamiento no tiene otra cosa que discurrir para ameni- zar la enervante monotonía de aquel paseo desabrido. ${ }^{43}$

La utilización de estos conceptos contrapuestos - cielo e infierno-, aparece en otras crónicas de la época para designar al Zócalo como el paraíso modernizado y los arrabales de indios como el infierno tradicional. Nuestra lectura de las crónicas de Ignacio Manuel Altamirano nos muestra a este autor, como a sus pares liberales, condenando constantemente los comportamientos de "la muchedumbre". Sin embargo, a pesar de tan severas críticas y planes, la fiesta continuó, con todo y quema de Judas (véase imagen 12).

En 1914, un antiguo y respetado miembro del Ayuntamiento insistía toda-

\footnotetext{
${ }^{43}$ Altamirano, "La vida en México", 1880, en Altamirano, Obras, 1986, pp. 82-83.
} 


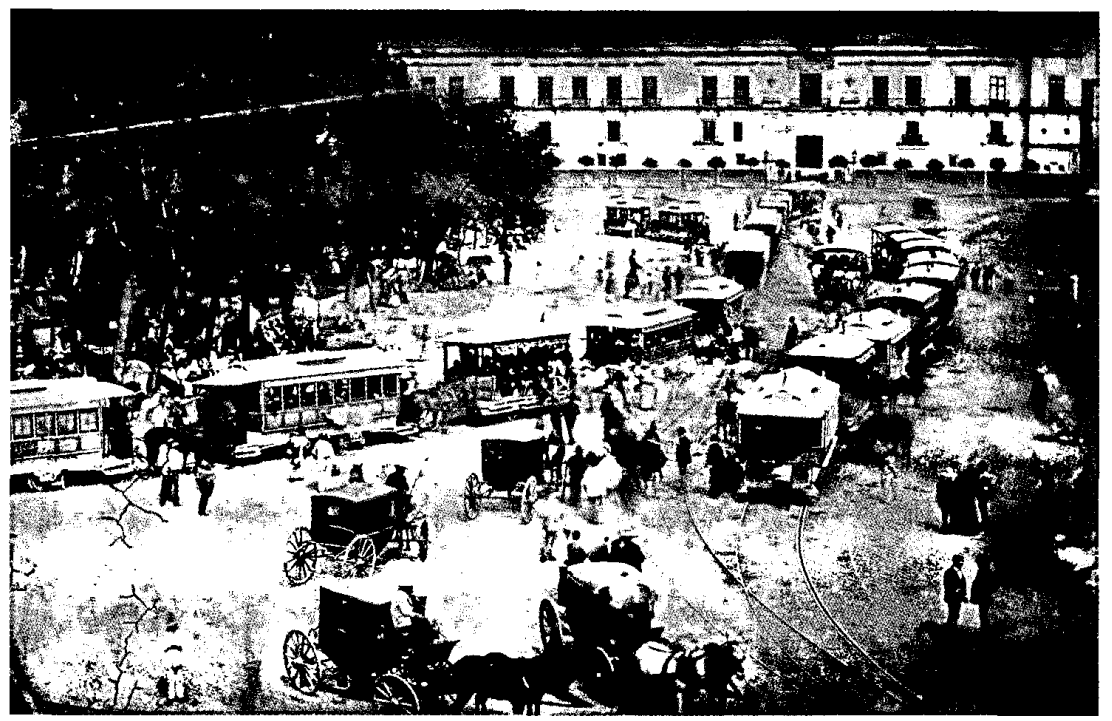

Imagen 11. Autor no conocido, sin título, ca. 1885, publicada en Valle-Arizpe, Palacio, 1936.

vía en un proyecto para modificar la plaza principal, quejándose de que "hoy en día se admiten en el recinto de la plaza, y en determinadas fechas, 'puestos' y vendimias de aspecto sucio y horrible, a los cuales, transformada la plaza, no se les daría cabida, porque son nuestra vergüenza." 44

Como ya se reseñó, aunque hubo una campaña para evitar cierto tipo de diversión durante las fiestas populares, éstos eran recurrentes durante las celebraciones cívicas - caballitos, circo, magia, fuegos artificiales-y otras muchas estuvieron presentes $e$ incluso fueron promovidas por el poder, aunque fomentaban su desplazamiento hacia otros espacios menos cen-

$$
{ }^{44} \text { Galindo, "Plaza", 1926, p. } 87 .
$$

trales. Otras prácticas que se trataban de impedir a toda costa, como la bebida y la comida callejera, se impusieron en pleno Zócalo capitalino a pesar de todas las restricciones.

Las explicaciones a estos procesos se pueden hacer en distintos sentidos no necesariamente excluyentes: bien porque los permisos dejaban dinero al Ayuntamiento, bien porque era algo que se le imponía a la elite y, también, la razón menos explorada en este artículo, porque en este insistir se daban elementos de índole clasista contra la elite liberal. La primera, para el caso del comercio y como hemos apuntado aquí, reside en que los combates del Ayuntamiento contra prácticas seculares de los habitantes, arraigadas y vi- 


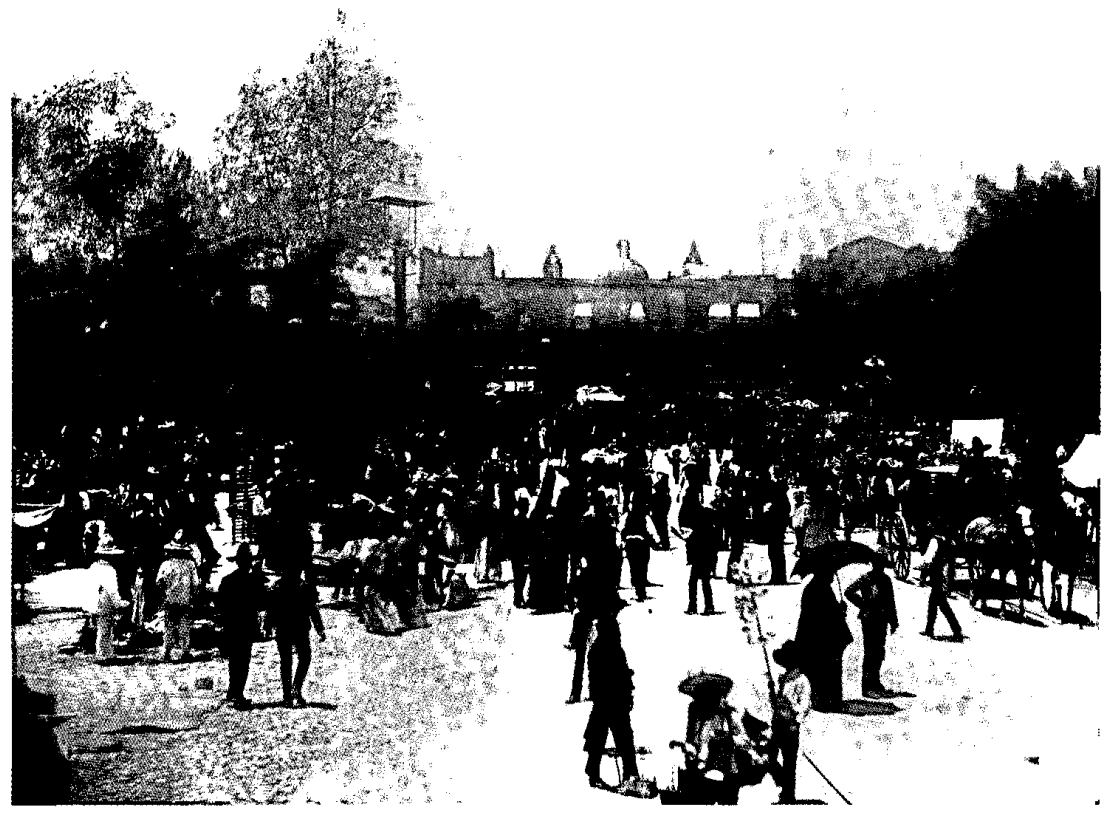

Imagen 12. Autor no conocido, sin título, ca. 1890, publicada en Matabuena, Álbum, 2000, p. 22.

gentes en la medida en que significaban una fuente de vida para muchos de ellos, tenían como límite la permisividad de las autoridades para hacerse de recursos. Las personas que vendían entretenimiento, comida o bebida en el Zócalo se rebelaban contra la política impuesta por los liberales decimonónicos no sólo por costumbre, sino porque estaban imposibilitados de pagar las rentas que hubieran tenido que pagar en mercados, y seguramente también porque obtenían mejores ingresos en el Zócalo. Por otro lado, los puestos y las diversiones con los que la elite no estaba de acuerdo en principio dejaban recur- sos a más de uno, por eso "el Ayuntamiento nunca obtuvo victorias definitivas o irreversibles". 45

Otra explicación es que, independientemente de las prohibiciones, al existir una postura de fuerza de la población, las autoridades tenían que ceder, lo cual es claro en la forma en que se hacen las celebraciones cívicas, pues con sólo discursos y otras manifestaciones oficiales, las fechas de la nación dejarían de tener el atractivo que en efecto tuvieron y siguen teniendo.

${ }^{45}$ López, Ciudad, 1985, p. 111. 
Finalmente, la plaza, a pesar de las transformaciones que sufrió, tendientes a expulsar a los habitantes de menores recursos, siguió siendo punto de referencia obligado. ${ }^{46}$ La mayoría de los habitantes de la ciudad de México, con todo y las reiteradas prohibiciones de que en este espacio recrearan sus relaciones sociales, insistentemente volvían a la plaza para hacerla suya aunque fuera momentáneamente. El propio 15 de septiembre, durante el siglo XIX, como ya señaló Alejandra Moreno Toscano, no consistía en una ceremonia impuesta ritualmente, pues su origen arranca de una lucha popular. ${ }^{47}$ Una referencia a este sello clasista de las festividades se puede observar en una lectura de la crónica de Ángel de Campo, "Los peligros del grito" 48 en la que "los rotos" sufren toda clase de maltratos y despojos de parte del bajo pueblo que asiste.

La mayoría de quienes han abordado los estudios de la "modernidad" o de las fiestas ciudadanas tienden fácilmente a dejarse llevar por las intenciones de la elite, por los discursos de los intelectuales liberales, dejando de lado esta persistencia de los desposeídos en sus formas de vida y diversión, que claramente podemos encontrar en diversas fuentes. ${ }^{49}$ Por eso se

${ }^{46}$ Véase Ribera, "Plaza", 2002.

${ }^{47} \mathrm{La}$ gente va a celebrar a la plaza la resistencia del pueblo contra el invasor de 1847 y la entrega de las autoridades, especialmente las municipales. Véase Moreno, "Trabajadores", 1984.

${ }^{48}$ Campo, Semana, 1991, pp. 132-135.

${ }^{49}$ En su estudio sobre Orizaba, Ribera Carbó se aleja de este espejismo liberal y afirma que el poder se esmera en modelar el espacio urbano de acuerdo con sus intereses, en especial las plazas, que son símbolo desde donde la burguesía expresa su dominio. Ribera, Herencia, 2002, pp. 10 y 294. hace necesario desarrollar investigaciones que, acudiendo y analizando, entre otros documentos, a las imágenes, tomen en cuenta las acciones y planes de distintos grupos sociales, que muchas veces generan situaciones conflictivas.

Este asunto no carece de limitantes. En el caso de las fuentes gráficas, aunque no exclusivamente, la mayoría de las imágenes que sobreviven, o incluso la mayoría de las que se crearon en su momento, corresponden a este discurso de progreso y modernidad generado por el poder. No se trata únicamente de que muchos fotógrafos compartieran este punto de vista, sino, sobre todo, que el mercado para estas imágenes demandaba este tipo de vistas. Sin embargo, independientemente de esta situación, existen circunstancias en las que, en la medida que las cámaras captan escenas que no son totalmente controladas por los fotógrafos, aparecen procesos que nos pueden ayudar a descubrir aspectos interesantes en nuestras investigaciones.

Por otro lado, las fotografías tienen una limitante clara en sus posibilidades para enterarnos de los procesos sociales. En nuestro caso, vemos en ellas instalaciones, formas de vestir y hasta comportamientos no aceptados por la elite, pero no sabemos los objetivos e ideas que existen tras eso que percibimos superficialmente. Por eso un trabajo histórico con imágenes debe recurrir a la construcción de otro tipo de fuentes que puedan hacer más ricas nuestras explicaciones más allá de lo que se conoce como una lectura de imagen. La incorporación de fotografías en la investigación histórica tiene todavía un largo camino por recorrer, donde tendrá un papel central el estímulo a la conservación y rescate del patrimonio foto- 
gráfico, la creación de catálogos sólidos en los acervos y la construcción de metodologías para el análisis de la imagen como fuente. Sólo con más trabajos y mayor reflexión y discusión sobre estos tres aspectos ampliaremos las bases documentales, teóricas y metodológicas que nos permitirán seguir proponiendo y ensayando explicaciones más complejas a los procesos sociales que busquemos historiar, considerando estos vestigios visuales de los últimos dos siglos.

\section{ARCHIVOS}

AHDF Archivo Histórico del Distrito Federal.

\section{BIBLIOGRAFÍA}

-Aguayo, Fernando, "Los ferrocarriles de Tacubaya" en Celia Maldonado y Carmen Reyna (coords.), Tacubaya, pasado y presente I, Yeuetlatolli, México, 1998.

y Lourdes Roca (coords.), Imágenes e investigación social, Instituto Mora, México, en prensa.

-Aguayo, Fernando, Paris García, Carlos Hernández, Felipe Morales y Lourdes Roca, Revelando el rollo, Instituto Mora, México, 2002, vHS.

-Altamirano, Ignacio Manuel, Obras completas V. Textos costumbristas, SEP, México, 1986.

-Ayuntamiento Constitucional de México, Discurso pronunciado por el Dr. Manuel Domínguez, regidor $1^{\circ}$ del Ayuntamiento constitucional de México en 1880, al separarse del puesto conforme a la ley, el $1^{\circ}$ de enero de 1881, Imprenta de Francisco Díaz de León, México, 1881.

, Discurso pronunciado por el Sr. Pedro Rincón Gallardo, regidor $1^{\circ}$ del Ayuntamiento Constitucional de México en 1881, al separarse del puesto, conforme a la ley, el $1^{\circ}$ de enero de 1882, Imprenta del Comercio de Dublán y Cía., México, 1882. , Reseña leída por el presidente municipal en nombre de la corporación que funcionó en 1882. Contestación del Lic. Guillermo Valle y discurso del C. gobernador del Distrito Federal, Imprenta de Francisco Díaz de León, México, 1882.

, Discurso leído el $1^{\circ}$ de enero de 1884 por el C. Pedro Rincón Gallardo como presidente del Ayuntamiento de 1883, dando cuenta de su administración. Contestación del Lic. Guillermo Valle, presidente del Ayuntamiento de 1884, Imprenta de Francisco Díaz de León, México, 1884.

- Discurso leído el $1^{\circ}$ de enero de 1885 por el C. Guillermo Valle como presidente del Ayuntamiento de 1884, dando cuenta de su administración. Contestación del C. Pedro Rincón Gallardo, presidente del Ayuntamiento de 1885, Imprenta de Francisco Díaz de León, México, 1885.

, Discurso leído el $1^{\circ}$ de enero de 1886 por el C. Pedro Rincón Gallardo, dando cuenta de su administración. Contestación del C. Manuel González Cosío, presidente del Ayuntamiento de 1886, Imprenta de Francisco Díaz de León, México, 1886.

-Campo, Ángel de, La semana alegre, UNAM, México, 1991.

-Charnay, Desiré, "Mis descubrimientos en México y en la América Central" en América pintoresca, Montaner y Simón, Barcelona, 1884.

-Galindo y Villa, Jesús, "La Plaza Mayor de la ciudad de México", Magazine de Geografía Nacional, núms. 7 y 8, julio-agosto de 1926, t. II.

-García Cubas, Antonio, Apuntes relativos a la población de la república mexicana, Imprenta del Gobierno, México, 1870.

-Gortari Rabiela, Hira de, Memoria y encuentros: la ciudad de México y el Distrito Federal (1824-1928), DDF/Instituto Mora, México, 1988,3 tt.

-López Monjardín, Adriana, Hacia la ciudad del capital: México 1790-1870, INAH, México, 1985 (Cuaderno de Trabajo, 46). 
-Matabuena Peláez, María Teresa, Álbum. La capital de México, 1876-1900, Universidad Iberoamericana, México, 2000.

-Moreno Toscano, Alejandra, "Los trabajadores y el proyecto de industrialización, 1810 1867" en La clase obrera en la bistoria de México, Siglo XXI, México, 1984, vol. 1.

-Moya, Arnaldo, "Los festejos cívicos septembrinos durante el porfiriato" en Claudia Agostini y Elisa Speckman (eds.), Modernidad, tradición y alteridad. La ciudad de México en el cambio de siglo, UNAM, México, 2001.

-Mraz, John, Ensayos sobre historia gráfica, UAP, México, 1996.

-Ribera Carbó, Eulalia, "La plaza pública como elemento de integración, centralidad permanencia en las ciudades mexicanas" en Los espacios priblicos de la ciudad siglos XVIII y XIX, Casa Juan Pablos/ICCM, México, 2002.

- Herencia colonial y modernidad burguesa en un espacio urbano. El caso de Orizaba en el siglo XIX, Instituto Mora, México, 2002 (Historia Urbana y Regional).
-Rivera Cambas, Manuel, México pintoresco, artístico y monumental, Nacional, México, 1880.

-Rodríguez Kuri, Ariel, "Gobierno local y empresas de servicios: la experiencia de la ciudad de México en el porfiriato" en Sandra Kuntz Ficker y Priscilla Connolly (coords.), Ferrocarriles y obras públicas, Instituto Mora/El Colegio de Michoacán/CoLmeX/IIH-UNAM, México, 1999.

- Tovar y de Teresa, Guillermo, I a ciudad de los palacios: crónica de un patrimonio perdido, Vuelta, México, 1992.

-Valadés, José C., Orígenes de la repiblica mexicana, Editores Mexicanos Unidos, México, 1982.

-Valle-Arizpe, Artemio de, El Palacio Nacional de México. Monografía bistórica y anecdótica, Imprenta de la Secretaría de Relaciones Exteriores, México, 1936.

-Viqueira Alban, Juan Pedro, ¿Relajados o reprimidos? Diversiones públicas y vida social en la ciudad de México durante el Siglo de las Luces, FCE, México, 1987. 